\title{
Pharmacological and clinical evidence of nevirapine immediate- and extended-release formulations
}

This article was published in the following Dove Press journal:

HIVIAIDS - Research and Palliative Care

14 November 2012

Number of times this article has been viewed

\author{
Javier Ena \\ Concepción Amador \\ Conxa Benito \\ Francisco Pasquau \\ HIV Unit, Hospital Marina Baixa, \\ Villajoyosa, Spain
}

Correspondence: Javier Ena HIV Unit, Hospital Marina Baixa, 7 Av Alcalde Jaime Botella Mayor, Villajoyosa, Alicante 03570, Spain

Tel +3496 6859957

Fax +3496 6859900

Emailena_jav@gva.es

\begin{abstract}
We reviewed the current information available on nevirapine immediate- and extended-release formulations and its role in single-dose and combination antiretroviral therapy. Nevirapine was approved in 1996 and was the first non-nucleoside reverse-transcriptase inhibitor available for the treatment of HIV-1 infection. Nevirapine has demonstrated good efficacy and a well-characterized safety profile. A major drawback is the low genetic barrier, allowing the emergence of resistance in the presence of single mutations in the reverse-transcriptase gene. This shortcoming is particularly relevant when nevirapine is administered in a single dose to prevent mother-to-child transmission of HIV-1 infection, compromising the efficacy of future non-nucleoside reverse transcriptase-inhibitor regimens. Studies published recently have probed the noninferiority of nevirapine compared to ritonavir-boosted atazanavir with both tenofovir disoproxil fumarate and emtricitabine in antiretroviral treatment-naïve patients. In 2011, a new formulation of nevirapine (nevirapine extended release) that allowed once-daily dosing was approved by the Food and Drug Administration and by the European Medicines Agency. VERxVe, a study comparing nevirapine extended release with nevirapine immediate release in antiretroviral treatment-naïve patients, and TRANxITION, a study carried out in antiretroviral treatment-experienced patients who switched therapy from nevirapine immediate release to nevirapine extended release, provided data on the noninferiority of the new formulation of nevirapine compared with nevirapine immediate release in terms of efficacy and safety. Nevirapine extended release will further increase the durability and persistence of nevirapine-containing antiretroviral therapy, allowing once-daily dosing regimens.
\end{abstract}

Keywords: nevirapine extended release, efficacy, safety, resistance, clinical practice

\section{Introduction}

Nevirapine is a non-nucleoside reverse-transcriptase inhibitor with an extensive history. It was approved in 1996 by the US Food and Drug Administration for use in adult patients infected with HIV-1 and thereafter by the European Medicines Agency in 1997; in 1998, nevirapine was approved for use in children.

Trials in antiretroviral treatment-naïve patients carried out early this century showed that nevirapine had a comparable efficacy to indinavir, nelfinavir, and efavirenz. Due to its high potency, no food effect, low pill burden, and low cost, antiretroviral drug combinations containing nevirapine are considered first-line regimens in developing countries. . $^{1,2}$

The major disadvantages of nevirapine are the risk of serious adverse effects, such as hepatotoxicity and cutaneous reactions, related to baseline CD4 lymphocyte cell 
counts, ${ }^{3}$ and the low genetic barrier, allowing the emergence of resistance with single mutations in the reversetranscriptase gene. ${ }^{4}$

Nevirapine is available as 200-mg tablets and as oral solution - $50 \mathrm{mg}$ per $\mathrm{dL}$ ( $240-\mathrm{mL}$ bottle). The recommended dose is $200 \mathrm{mg}$ once daily for the first 2 weeks, and then $200 \mathrm{mg}$ twice daily. A new formulation of nevirapine - nevirapine extended-release (XR) - has been developed for the purpose of daily dosing at $400 \mathrm{mg}$ (administered after a 200-mg daily lead-in period). For pediatric populations, nevirapine XR is also available in 100-mg and 50-mg tablets. ${ }^{5}$

An extended-release formulation of nevirapine may offer improved treatment options for once-daily antiretroviral regimens, with greater convenience and patient adherence. In this review, we summarize the current information available on nevirapine immediate-release (IR) and XR formulations and its role in single-dose and combination antiretroviral therapy.

\section{Search strategy and selection criteria}

We searched Medline by using the medical subject heading terms ("nevirapine" [MeSH terms] or "nevirapine" [all fields]) and extended-release (all fields) or (("nevirapine" [MeSH Terms] or "nevirapine" [all fields]) and XR [all fields]) between March 2008 and June 2012, but we did not exclude commonly referenced and highly regarded older publications. We also searched the reference lists of review articles on nevirapine for additional papers we judged to be relevant for this review.

\section{Mode of action}

Nevirapine is structurally a member of the dipyridodiazepinone chemical class of compounds, and is a non-nucleoside reverse-transcriptase inhibitor with activity against HIV-1. ${ }^{6}$ Nucleoside and non-nucleoside reverse-transcriptase inhibitors inhibit the same target: the reverse-transcriptase enzyme, an essential viral component which transcribes viral RNA into DNA. Unlike nucleoside reverse-transcriptase inhibitors, which bind at the enzyme's active site, nevirapine binds allosterically at a distinct site away from the active site termed the non-nucleoside reverse transcriptase-inhibitor pocket. Since the pocket of the HIV-2 reverse-transcriptase enzyme has a different structure, HIV-2 is intrinsically resistant to nevirapine. ${ }^{?}$

Nevirapine is associated with rapid and high-level resistance if viral replication is not completely suppressed. ${ }^{7}$ A number of primary reverse-transcriptase mutations, such as K103N, L100I, Y181C/I, Y188C/L/H, and G190A, have been identified, resulting in an increase in the $90 \%$ inhibitory concentration of greater than 100 -fold. ${ }^{8}$ Low trough plasma nevirapine concentrations are a major determinant for emergence of virological failure and resistant mutations. ${ }^{9}$ A nevirapine trough concentration greater than $4300 \mathrm{ng} / \mathrm{mL}$ was found to predict longer viral suppression. ${ }^{10}$ Emergence of nevirapine resistance determines the presence of crossresistance with delavirdine. Nevirapine cross-resistance with efavirenz is more variable, and in vitro is commonly seen with $\mathrm{K} 103 \mathrm{~N}$ mutation. ${ }^{11}$ Using nevirapine is also associated with intermediate and reduced response to etravirine among HIV-infected patients who experienced virologic failure in resource-limited settings. ${ }^{12}$

Data from a randomized clinical trial comparing frequency and patterns of resistance between nevirapine IR and nevirapine XR (VERxVe trial) showed similar frequency and resistance patterns in both antiretroviral-treatment regimens, Y181C being the most commonly detected resistant mutation. $^{13}$

\section{Pharmacokinetics Absorption}

Nevirapine XR 400-mg tablets should be swallowed whole with or without food. ${ }^{14}$ Nevirapine XR has shown greater bioavailability when it is administered with food than with an empty stomach. Nevertheless, the bioavailability of nevirapine XR $400 \mathrm{mg}$ is only $80 \%$ of nevirapine IR $200 \mathrm{mg}$ administered twice daily at a steady state. ${ }^{15}$

\section{Distribution}

Nevirapine XR distributes widely, crosses placenta, enters breast milk, and penetrates central nervous system with a concentration approximately $50 \%$ of plasma (cerebrospinal fluid plasma ratio, 0.50). $C_{\max }$ is $2-4 \mathrm{mg} / \mathrm{L}$, and the area under the curve (AUC) value is $108.1 \mathrm{mg} /$ hour/L. Sixty percent of nevirapine XR binds to protein. The distribution volume is $1-4 \mathrm{~L} / \mathrm{kg}$. Metabolism is mainly hepatic via cytochrome CYP3A4 by hydroxylation to inactive compounds. Nevirapine XR provides similar trough concentrations $\left(C_{\min }\right.$ at steady state) as nevirapine IR; however, missing one dose of nevirapine XR has a greater effect than missing one dose of nevirapine IR twice daily, because a larger amount of drug exposure is lost. Half-life elimination decreases due to autoinduction from 45 hours initially to 23 hours after $2-4$ weeks of dosing. ${ }^{16}$

\section{Metabolism and elimination}

Nevirapine is biotransformed via cytochrome CY3A4 to several metabolites. ${ }^{17}$ Studies using $\mathrm{C}^{14}$-nevirapine isotopic 
labeling show that $80 \%$ of the drug is eliminated by urine as glucuronide conjugates of hydroxylated metabolites, less than $5 \%$ is eliminated as unmodified nevirapine, and $10 \%$ is eliminated by feces.

\section{Nevirapine $\mathbf{X R}$ dosing}

Adult patients aged 16 years or older should start treatment with $200 \mathrm{mg}$ nevirapine IR as a lead-in to reduce the risk of adverse drug reactions. ${ }^{14}$ Then, nevirapine XR $400 \mathrm{mg}$ should be administered once daily. Treatment should be started in combination with two additional antiretroviral drugs, the most common being tenofovir disoproxil fumarate/emtricitabine and zidovudine/lamivudine. Patients taking nevirapine IR twice daily can be switched to nevirapine XR $400 \mathrm{mg}$ without a lead-in period. Laboratory blood tests, including liver-function tests, should be performed prior to starting therapy with nevirapine and should be continued at appropriate intervals. In cases of appearance of rash during the 14-day lead-in period, patients should not start with nevirapine XR $400 \mathrm{mg}$ until the cutaneous reaction has resolved. The 200-mg lead-in dose should not be continued beyond 28 days, at which point an alternate regimen should be sought. Patients who stop nevirapine XR for more than 7 days should restart the same regimen using a 2-week lead-in period of nevirapine IR.

\section{Dosing in special populations Elderly}

Nevirapine XR has not been investigated in the elderly. However, the pharmacokinetic parameters of nevirapine IR do not significantly change in patients with HIV-1 infection in the age range $19-68$ years.

\section{Children}

Children's dosage is $150-200 \mathrm{mg} / \mathrm{m}^{2}$ every 12 hours for the first 2 weeks at the lowest dose; in neonates (up to 3 months of age), start with $5 \mathrm{mg} / \mathrm{kg}$ per day for 2 weeks and increase to $200 \mathrm{mg} / \mathrm{m}^{2}$ every 12 hours. Nevirapine XR has not been studied in children less than 3 years old. An open-label, multiple-dose, crossover study carried out in 85 patients aged 3-18 years, nevirapine XR exhibited pharmacokinetic profiles that provided adequate geometric trough levels to maintain efficacy and was well tolerated. ${ }^{18}$

Nevirapine-based antiretroviral therapies are common regimens used in children from developing countries. However, it should be taken into account that nevirapine efficacy is reduced in children who have been exposed to single-dose nevirapine for the prevention of perinatal HIV-1 transmission, being nevirapine regimens inferior to ritonavir-boosted lopinavir regimens. ${ }^{19}$
Short-course zidovudine and lamivudine supplementing maternal and infant single-dose nevirapine reduces emergent non-nucleoside reverse transcriptase inhibitor-resistance mutations in both mothers and their infants. ${ }^{20}$ Factors that may contribute to the suboptimal results of nevirapine are the very high viral load (greater than 500,000 copies/mL) commonly observed in children and the standard lead-in dosing strategy, as has been shown in the P1060 study. ${ }^{19}$

\section{Sex}

Female patients had approximately $20 \%-30 \%$ higher plasma concentrations than males after being treated with either nevirapine XR or nevirapine IR. In the large, multinational 2NN study, analyzing the efficacy and safety of nevirapine IR compared to efavirenz, plasma concentrations of nevirapine in females were $13.8 \%$ higher than in males. There was no relationship with body weight, suggesting an independent sex effect. ${ }^{21}$

Recent data in HIV-1-infected women have provided support for the continued use of nevirapine as a first-line treatment option in the absence of previous exposure to this drug. The OCTANE A5208 trial showed that nevirapine, administered as initial treatment in HIV-1-infected women without previous exposure to single-dose nevirapine during pregnancy, was noninferior to ritonavir-boosted lopinavir with respect to virological failure and death. ${ }^{22}$ However, for women who had been exposed to single-dose nevirapine, significantly more of them reached the primary end point (virological failure, emergence of resistance, and mortality) when they were compared with the ritonavir-boosted lopinavir group. ${ }^{22}$

\section{Weight}

The 2NN substudy on pharmacokinetics showed no influence of either body weight or body mass index on the clearance of nevirapine in a total of 1077 enrolled patients. ${ }^{21}$

\section{Race}

Nevirapine IR pharmacokinetic parameters did not appear to change with race (black, Hispanic, or Caucasian). ${ }^{23}$ However the study 1100.1486 (VERxVE trial) showed that black patients had $30 \%$ higher trough concentrations after treatment with either nevirapine XR or nevirapine IR. ${ }^{13}$ The clinical relevance of such difference in nevirapine XR concentration in black patients has not been analyzed.

\section{Impaired renal function}

There is a lack of information on the effects of renal impairment on exposure to nevirapine XR. Nevirapine is extensively 
metabolized by the liver, and nevirapine metabolites are eliminated by the kidney, with less than 5\% unchanged in the urine. Experience with nevirapine IR shows that it is not necessary to modify dosing even with moderate or severe renal dysfunction. However, for patients with end-stage kidney disease who are on hemodialysis, there is a $43.5 \%$ reduction in plasma AUC. That situation can be managed by supplementing nevirapine with an additional 200-mg dose following each dialysis treatment. ${ }^{24}$

\section{Impaired hepatic function}

Nevirapine XR has not been evaluated in patients with hepatic impairment. The available information comes from a small study analyzing the steady state of nevirapine IR $200 \mathrm{mg}$ twice daily in 46 adult patients with HIV-1 infection and mild liver fibrosis, moderate fibrosis, and cirrhosis, with a median duration of treatment of 3.4 years. In general terms, exposure was increased in proportion to the degree of hepatic impairment: $15 \%$ of patients had trough nevirapine concentrations greater than $9.0 \mu \mathrm{g} / \mathrm{mL} .{ }^{25}$ As the exposure with nevirapine XR is less than that with nevirapine IR, the risk of adverse reactions is no more likely if the established precautions are observed.

\section{Interactions}

Nevirapine XR formulation has not been specifically evaluated in interaction studies. However, there is no reason to expect drug interactions with nevirapine XR formulations to differ qualitatively from nevirapine IR. Therefore, precautions regarding drug interactions observed with the nevirapine IR formulation would also need to be followed with the XR formulation (Table 1$).^{5}$

Data obtained from numerous drug-interaction studies testing nevirapine IR against other antiretroviral drugs,

Table I Drugs in which plasma concentrations may be decreased by coadministration with nevirapine

\begin{tabular}{ll}
\hline Drug class & Type of drug \\
\hline Antiarrhythmics & Amiodarone, disopyramide, lidocaine \\
Antibiotics & Clarithromycin, rifampin \\
Anticonvulsants & Carbamazepine, clonazepam, ethosuximide \\
Antifungals & Ketoconazole, itraconazole, voriconazole \\
Antithrombotics & Warfarin \\
Calcium-channel blockers & Diltiazem, nifedipine, verapamil \\
Cancer chemotherapy & Cyclophosphamide \\
Ergot alkaloids & Ergotamine \\
Immunosuppressants & Cyclosporin, tacrolimus, sirolimus \\
Motility agents & Cisapride \\
Opiate agonists & Fentanyl, methadone \\
Oral contraceptives & Ethinyl estradiol \\
Statins & Lovastatin, simvastatin, atorvastatin \\
\hline
\end{tabular}

antibiotics, antifungals, antacids, contraceptives, drugs of addiction, and St John's Wort show potential interactions with compounds that are substrates for CYP3A and CYP2B6.

The most important drugs requiring dose modification with concurrent use with nevirapine are listed below. ${ }^{5}$

\section{Oral contraceptives}

Nevirapine decreases AUC for ethinyl estradiol by about $30 \%$; alternative or additional methods of birth control should be used.

\section{Clarithromycin}

Nevirapine reduces clarithromycin AUC by $30 \%$. But on the other hand, it increases the levels of its 14-OH metabolite, which has antibacterial activity that compensates for this reduction; therefore, no dose adjustment is required. Nevertheless, nevirapine levels increased 26\%. The recommendation is using standard doses and monitor or better use azithromycin.

\section{Ketoconazole}

Ketoconazole levels decrease by about 63\% and nevirapine increases $15 \%-30 \%$; this association is not recommended.

\section{Voriconazole}

Although there are no data, a potential decrease in voriconazole levels and increase in nevirapine levels are expected. This association is not recommended.

\section{Rifabutin}

Rifabutin levels are decreased by $16 \%$; no dose alteration is required.

\section{Rifampin}

There is a decrease in nevirapine AUC of $20 \%-58 \%$. A pharmacokinetic study has recently shown that in cotreated patients, nevirapine concentration was below the minimum effective concentration during initiation with dose escalation. ${ }^{26}$ Randomized clinical trials have demonstrated that antiretroviral therapy regimens containing efavirenz (600 mg per day) were less compromised by concomitant use of rifampicin than were those that contained nevirapine (400 mg per day) in patients with concurrent HIV-1 infection and tuberculosis. Low drug exposure and low body weight were important predictive factors for nevirapine treatment failure. ${ }^{27}$ In fact, this trial was halted by the data and safety monitoring board at the second interim analysis. Favorable tuberculosis treatment outcomes were observed in $93 \%$ of 
patients in the efavirenz arm and $84 \%$ of the patients in the nevirapine arm $(P=0.058)$. However, the proportion of severe liver toxicity was very low in both groups (two patients in the nevirapine arm and one patient in the efavirenz arm). ${ }^{28}$ In a comparative trial including 142 patients starting tuberculosis treatment while receiving non-nucleoside reverse transcriptase inhibitor-based antiretroviral therapy, nevirapine showed a greater risk of severe hepatotoxicity compared to efavirenz, although the rate was very low (three patients on nevirapine and one patient on efavirenz). The study identified infection caused by the hepatitis $\mathrm{C}$ virus as a main determinant for suffering from severe liver toxicity. ${ }^{29}$

\section{Phenobarbital, phenytoin, carbamazepine}

There are no data. It is necessary to monitor anticonvulsivant levels; nevirapine levels might be reduced.

\section{Acid-reducing agents}

Food or antacids do not affect the absorption of nevirapine.

\section{Hydroxymethylglutaryl coenzyme A reductase inhibitors}

Hypercholesterolemia and high cardiovascular risk are a major concern in patients with HIV. Nevirapine IR and nevirapine XR show a favorable effect on lipid profile that may be of clinical benefit in reducing the risk for coronary artery disease in patients with HIV-1 infection. Moreover, nevirapine showed a potentially less atherogenic lipid profile compared with ritonavir-boosted atazanavir. ${ }^{30}$ However, patients may require additional reduction in plasma lipid concentrations by means of hydroxymethylglutaryl coenzyme A reductase inhibitors (statins). Since nevirapine increases the activity of CYP3A during long-term treatment, patients would be expected to require greater doses of statins to achieve lowdensity lipoprotein cholesterol goals. To prevent toxicity associated with statin therapy, the use of drugs metabolized by alternative pathways to CYP3A, such as pitavastatin, rosuvastatin, or pravastatin, is recommended. ${ }^{31}$

\section{Methadone}

When introducing efavirenz or nevirapine to patients undergoing methadone treatment, withdrawal symptoms should be monitored, especially insomnia, vomiting, or nausea. It has been suggested to monitor methadone plasma trough and peak measurements to prevent unnecessary side effects of antiretroviral combination therapy. ${ }^{32}$ Pharmacokinetic studies suggest increasing the methadone dose by $30 \%$ to prevent withdrawal symptoms. ${ }^{33}$

\section{Other antiretroviral drugs}

There is not much experience with nucleoside-sparing regimens in clinical practice. Possible clinical scenarios to use such regimens could be the presence of mitochondrial toxicity, an advanced kidney disease, or the emergence of thymidine analog-resistant mutations. A small pilot trial showed that the combination of nevirapine and ritonavirboosted lopinavir at standard dosing can maintain viral suppression at 48 weeks with improvements in mitochondrial parameters. $^{34,35}$ There is no clinical experience with other nucleoside-sparing regimens using nevirapine and other protease inhibitors. In the case of atazanavir, the recommended dose should be $300 \mathrm{mg}$ with $100 \mathrm{mg}$ of ritonavir per day, and for saquinavir the recommended dose should be $1000 \mathrm{mg}$ with $100 \mathrm{mg}$ of ritonavir twice a day. Other protease inhibitors should be used with the same dosing when combined with nevirapine as nucleoside-sparing regimens.

\section{Clinical efficacy}

The majority of recent clinical data regarding nevirapine efficacy have been produced with nevirapine IR with doses of $200 \mathrm{mg}$ twice a day and mainly in antiretroviral-naïve patients or as a switching strategy (Table 2).

\section{Nevirapine in antiretroviral treatment-naïve patients}

The $2 \mathrm{NN}$ trial was a large, randomized, comparative, openlabel trial of several regimens containing either nevirapine, efavirenz, or both drugs combined in addition to stavudine and lamivudine. ${ }^{21}$ This multinational study included 1216 antiretroviral treatment-naïve patients; 220 of them were randomized to nevirapine IR $400 \mathrm{mg}$ once daily, 387 to nevirapine IR $200 \mathrm{mg}$ twice daily, 400 to efavirenz, and 209 to the nevirapine IR plus efavirenz group. Patients were analyzed by intention to treat. Treatment success was considered in $56.4 \%$ in the nevirapine once-daily arm, $56.3 \%$ in the nevirapine twice-daily arm, $62.2 \%$ in the efavirenz arm, and $46.9 \%$ in the nevirapine plus efavirenz arm. There was no significant difference in virologic response among groups. The proportion of patients achieving an HIV-1 RNA concentration of fewer than 50 copies $/ \mathrm{mL}$ at week 48 was $65 \%$ for nevirapine once daily, $63.3 \%$ for nevirapine twice daily, $67.8 \%$ for efavirenz, and $61.7 \%$ for nevirapine plus efavirenz. However, the difference in treatment failure between nevirapine IR twice daily compared to efavirenz was 5.9\% (95\% confidence interval, $-0.9 \%$ to $12.8 \%$ ). These results failed to demonstrate the noninferiority of nevirapine IR compared to efavirenz. When this clinical trial was carried 
Table 2 Summary of most relevant randomized clinical trials on nevirapine efficacy

\begin{tabular}{|c|c|c|c|c|}
\hline Trial & Population & Intervention & Outcome & Follow-up \\
\hline $\begin{array}{l}\text { PI060 } \\
\text { study } \\
2012\end{array}$ & $\begin{array}{l}\text { Children ( } 85 \% \text { had oral } \\
\text { documentation of prior single-dose } \\
\text { nevirapine exposure to prevent } \\
\text { mother-to-child transmission) } \\
\mathrm{n}=288\end{array}$ & $\begin{array}{l}\text { Nevirapine-IR vs ritonavir- } \\
\text { boosted lopinavir, both with } \\
\text { zidovudine and lamivudine }\end{array}$ & $\begin{array}{l}\text { HIV-I RNA concentration of fewer } \\
\text { than } 400 \text { copies per mL; } \\
75.0 \% \text { vs } 84.9 \% \text {, respectively; risk } \\
\text { difference }(R D) 9.72 \%(95 \% \text { confidence } \\
\text { interval }[\mathrm{Cl}],-19.0 \text { to } 0.5 ; P=0.06)\end{array}$ & 48 weeks \\
\hline $\begin{array}{l}\text { OCTANE }{ }^{22} \\
2010\end{array}$ & $\begin{array}{l}\text { Women with single-dose } \\
\text { exposure to nevirapine to prevent } \\
\text { mother-to-child transmission } \\
n=24 \text { I }\end{array}$ & $\begin{array}{l}\text { Nevirapine-IR vs ritonavir- } \\
\text { boosted lopinavir, both with } \\
\text { tenofovir disoproxil fumarate/ } \\
\text { emtricitabine }\end{array}$ & $\begin{array}{l}\text { HIV-I RNA concentration of fewer } \\
\text { than } 400 \text { copies per } \mathrm{mL} ; 77 \% \text { vs } 92 \% \text {, } \\
\text { respectively; RD, } 15.0 \% \\
(95 \% \mathrm{Cl},-24.3 \text { to }-5.9 ; P=0.00 \mathrm{I})\end{array}$ & 24 weeks \\
\hline $\begin{array}{l}\text { ARTEN }^{25} \\
2011\end{array}$ & $\begin{array}{l}\text { Adult antiretroviral } \\
\text { treatment-naive patients } \\
\mathrm{n}=569\end{array}$ & $\begin{array}{l}\text { Nevirapine-IR vs ritonavir- } \\
\text { boosted atazanavir, both with } \\
\text { tenofovir disoproxil fumarate/ } \\
\text { emtricitabine }\end{array}$ & $\begin{array}{l}\text { HIV-I RNA concentration of fewer } \\
\text { than } 50 \text { copies per } \mathrm{mL} ; 66.8 \% \text { vs } 64.8 \% \text {, } \\
\text { respectively; RD, } 2.1 \%(95 \% \mathrm{Cl},-6.0 \\
\text { to } 10.6 ; P=0.6 \mathrm{I})\end{array}$ & 48 weeks \\
\hline $\begin{array}{l}\text { NEWART }{ }^{27} \\
2011\end{array}$ & $\begin{array}{l}\text { Adult antiretroviral } \\
\text { treatment-naïve patients } \\
\mathrm{n}=152\end{array}$ & $\begin{array}{l}\text { Nevirapine-IR vs ritonavir- } \\
\text { boosted atazanavir, both with } \\
\text { tenofovir disoproxil fumarate/ } \\
\text { emtricitabine }\end{array}$ & $\begin{array}{l}\text { HIV-I RNA concentration of fewer } \\
\text { than } 50 \text { copies per } \mathrm{mL} ; 61.3 \% \text { vs } 64.9 \% \text {, } \\
\text { respectively; RD, }-2.6 \%(95 \% \mathrm{Cl},-17.8 \\
\text { to } 12.7 ; P=0.74)\end{array}$ & 48 weeks \\
\hline $\begin{array}{l}\text { VERxVE } \\
2011\end{array}$ & $\begin{array}{l}\text { Adult antiretroviral } \\
\text { treatment-naïve patients } \\
\mathrm{n}=10 \mathrm{II}\end{array}$ & $\begin{array}{l}\text { Nevirapine-XR vs nevirapine-IR, } \\
\text { both with tenofovir disopropil } \\
\text { fumarate/emtricitabine }\end{array}$ & $\begin{array}{l}\text { HIV-I RNA concentration of fewer } \\
\text { than } 50 \text { copies per } \mathrm{mL} ; 81.0 \% \text { vs } 75.9 \% \text {, } \\
\text { respectively; RD, } 5.1 \%(95 \% \mathrm{Cl}, 0.02 \\
\text { to } 10.2 ; P=0.04)\end{array}$ & 48 weeks \\
\hline $\begin{array}{l}\text { TRANxITION }{ }^{38} \\
2010\end{array}$ & $\begin{array}{l}\text { Adult antiretroviral } \\
\text { treatment-experienced } \\
\text { patients } \\
\mathrm{n}=443\end{array}$ & $\begin{array}{l}\text { Switching from nevirapine-IR } \\
\text { to nevirapine-XR (2:I) in patients } \\
\text { with HIV-I RNA of fewer than } \\
50 \text { copies/mL, combined with } \\
\text { either abacavir/lamivudine, tenofovir } \\
\text { disoproxil fumarate/emtricitabine } \\
\text { or zidovudine/emtricitabine }\end{array}$ & $\begin{array}{l}\text { HIV-I RNA concentration of fewer } \\
\text { than } 50 \text { copies per } \mathrm{mL} ; 88.8 \% \text { vs } 88.5 \% \text {, } \\
\text { respectively; RD, } 0.3 \%(95 \% \mathrm{Cl}-5.6 \\
\text { to } 7.3 ; P=0.90)\end{array}$ & 48 weeks \\
\hline
\end{tabular}

out, nevirapine treatment restrictions based on $\mathrm{CD}^{+} \mathrm{T}$-cell count criteria and sex did not apply. ${ }^{21}$

Recently, a nevirapine-based regimen was compared to ritonavir-boosted atazanavir to assess clinical efficacy and safety in the ARTEN study ${ }^{36}$ (Table 2). Both groups received a fixed dose of tenofovir disoproxil fumarate/emtricitabine as backbone. This randomized controlled clinical trial comprised 569 antiretroviral treatment-naïve patients from Europe and South America, with 376 in the nevirapine arm and 187 in the ritonavir-boosted atazanavir arm. The response rate at week 48 was $67 \%$ for the nevirapine IR group and $65 \%$ for the ritonavir-boosted atazanavir group. The study showed that nevirapine IR twice a day was noninferior to ritonavir-boosted atazanavir.

The NEWART is a multicenter study conducted in the US, designed to support the results from the ARTEN study. ${ }^{37}$ It is a randomized, open-label trial comparing twice-daily nevirapine IR with ritonavir-boosted atazanavir, using tenofovir disoproxil fumarate/emtricitabine as backbone. It includes 152 naïve patients, randomized $1: 1$ in two treatment groups; $89.5 \%$ of patients were males and $52 \%$ had an HIV-1 RNA concentration of $100,000 / \mathrm{mL}$ or more. At week
48 , the primary end point of virologic response was achieved in $61.3 \%$ patients with nevirapine IR and in $64.9 \%$ patients taking ritonavir-boosted atazanavir. The difference of $-4.1 \%$ was above the prespecified $-6.5 \%$ boundary, demonstrating that nevirapine IR was not inferior to ritonavir-boosted atazanavir.

The antiviral efficacy and safety of the new nevirapine XR formulation at $400 \mathrm{mg}$ once a day were compared to nevirapine IR $200 \mathrm{mg}$ twice per day in the VERxVE study. ${ }^{13}$ This is a phase III, randomized, multinational, double-blind, double-dummy, parallel-group, and activecontrolled clinical trial that included 1011 antiretroviral treatment-naïve patients with an HIV-1 RNA concentration of 1000 copies $/ \mathrm{mL}$ or more. Patients who met $\mathrm{CD}^{+}$ T-cell count criteria - 50-400 cells $/ \mathrm{mm}^{3}$ for males and 50-250 cells per $\mathrm{mm}^{3}$ for females - were stratified by baseline HIV-1 RNA concentration of fewer than 100,000 copies/mL and HIV-1 RNA concentration of 100,000 copies/mL or more, and randomized 1:1; 505 patients to nevirapine XR and 506 to nevirapine IR. Both groups started with $200 \mathrm{mg}$ nevirapine IR once daily for 14 days according to current recommendations, and the backbone 
regimen was fixed-dose tenofovir disoproxil fumarate plus emtricitabine. HIV-1 RNA concentration of fewer than 50 copies/mL at 48 weeks was achieved in $81 \%$ patients in the XR arm versus $75.9 \%$ in the IR arm using the time-to-lossof-virologic-response method to assess virological response. Nevirapine XR was shown not to be inferior to nevirapine IR according to a non-inferiority margin of $-10 \%$. Patients with a baseline HIV-1 RNA concentration of 100,000 copies/mL or less showed a higher virologic response for nevirapine $\mathrm{XR}$ and nevirapine IR (85.9\% versus $79.2 \%$ ) compared to those with HIV-1 RNA concentrations greater than 100,000 copies $/ \mathrm{mL} ; 73.2 \%$ versus $70.9 \%$ for nevirapine XR and nevirapine IR, respectively.

\section{Role of nevirapine $X R$ in nevirapine IR-treated patients}

The TRANxITION trial was an open-label, randomized, parallel-group study of switching patients treated with nevirapine IR twice daily to nevirapine XR. ${ }^{38}$ After 18 months of stable treatment with two nucleoside reverse-transcriptase inhibitors, (abacavir/lamivudine, tenofovir disoproxil fumarate/emtricitabine, or zidovudine/emtricitabine) plus nevirapine IR, patients were randomized 2:1 to XR $400 \mathrm{mg}$ per day or remained with their prior schedule of $200 \mathrm{mg}$ twice a day. In both groups, backbone nucleoside reversetranscriptase inhibitors were not changed.

Continued virological suppression was observed in 93.6\% (276 of 295) of nevirapine XR- and 92.6\% (137 of 148) of nevirapine IR-treated patients, an observed difference of $1 \%$ (95\% confidence interval -4.3 to 6.0$)$ at 24 weeks of follow-up. Noninferiority (adjusted margin of $-10 \%$ ) of nevirapine XR to nevirapine IR was robust and further supported by Snapshot analysis. At week 48, HIV-1
RNA was below the detection limit in $88.8 \%$ of patients in the XR group and in $88.5 \%$ in the IR group.

\section{Nevirapine for preventing mother- to-child HIV-I transmission}

Intrapartum and single-dose nevirapine has been extensively used for prevention of mother-to-child transmission of HIV-1 in developing countries. Nevirapine lowers the risk of HIV-1 transmission by nearly 50\% during the first 14-16 weeks of life in breastfed infants. ${ }^{39}$ The major drawback of this approach is the emergence of nevirapine resistance, which compromises future treatments with nevirapine combinations. ${ }^{40}$

In order to overcome the limited efficacy and the emergence of resistance when single-dose nevirapine has been given to mothers or children to prevent HIV-1, transmission two strategies have been evaluated. The first strategy consists of administration of combination antiretroviral therapy with three drugs compared with zidovudine plus single-dose nevirapine. The Kesho Bora study demonstrated that HIV-1 transmission rates were significantly greater when pregnant women received zidovudine twice daily and single-dose nevirapine at the onset of labor compared with ritonavir-boosted lopinavir with zidovudine plus lamivudine until cessation of breastfeeding or 6.5 months postpartum ${ }^{41}$ (Table 3 ). Another approach is to continue once-daily nevirapine to infants from age 6 weeks to age 6 months or until breastfeeding cessation. This latter approach significantly decreased the rate of HIV-1 transmission to infants from $2.4 \%$ to $1.1 \%{ }^{42}$ However, extended-dose nevirapine given to HIV-1 pregnant women who chose to breastfeed did not significantly reduce mother-to-child HIV-1 transmission compared to single-dose nevirapine given at labor. ${ }^{43}$

Table 3 Nevirapine for preventing mother-to-child HIV-I transmission

\begin{tabular}{|c|c|c|c|c|}
\hline Trial & Population & Intervention & Outcome & Follow-up \\
\hline $\begin{array}{l}\text { Kesho } \\
\text { Bora }^{41} \\
2011\end{array}$ & $\begin{array}{l}\text { Pregnant women } \\
\text { with HIV-I } \\
\text { infection, } \\
\mathrm{n}=824\end{array}$ & $\begin{array}{l}\text { Pregnant women starting therapy at } 28-36 \text { weeks; } \\
\text { zidovudine twice daily until delivery and a dose } \\
\text { of } 600 \mathrm{mg} \text { zidovudine plus } 200 \mathrm{mg} \text { nevirapine at the } \\
\text { onset of labor vs ritonavir-boosted lopinavir with } \\
\text { zidovudine plus lamivudine until cessation of breastfeeding } \\
\text { or to a maximum of } 6.5 \text { months postpartum }\end{array}$ & $\begin{array}{l}\text { HIV-I transmission at } 6 \text { weeks; } \\
9.5 \% \text { vs } 5.4 \% \text {, respectively; RD, } \\
4.1 \%(95 \% \mathrm{CI}, 0.5 \text { to } 7.8 ; P=0.029)\end{array}$ & 12 months \\
\hline $\begin{array}{l}\text { HPTN } \\
046^{42} \\
2012\end{array}$ & $\begin{array}{l}\text { Breastfed infants } \\
\text { without HIV-I } \\
\text { infection, } \\
n=1527\end{array}$ & $\begin{array}{l}\text { Once-daily infant nevirapine-IR from age } 6 \text { weeks } \\
\text { to } 6 \text { months or until breastfeeding cessation vs placebo }\end{array}$ & $\begin{array}{l}\text { HIV-I infection in infants at } \\
6 \text { months; incidence of HIV-I } \\
\text { infection I.I\% vs } 2.4 \% \text {; RD, I.3\% } \\
(95 \% \mathrm{CI}, 0 \text { to } 2.6 ; P=0.049)\end{array}$ & 6 months \\
\hline $\begin{array}{l}\text { SWEN }{ }^{43} \\
2011\end{array}$ & $\begin{array}{l}\text { Pregnant women with } \\
\text { HIV-I infection who } \\
\text { chose to breastfeed, } \\
n=1890\end{array}$ & $\begin{array}{l}\text { Single-dose nevirapine IR vs extended-dose nevirapine } \\
\text { IR through } 6 \text { weeks of age }\end{array}$ & $\begin{array}{l}\text { HIV-I infection in infants at } \\
\text { I } 2 \text { months; incidence of HIV-I } \\
\text { infection } 10.4 \% \text { vs } 8.9 \% \text {; RD, I.5\% } \\
(95 \% \mathrm{Cl},-\mathrm{I} . \mathrm{I} \text { to } 4.2 ; P=0.15)\end{array}$ & 12 months \\
\hline
\end{tabular}




\section{Safety and tolerability}

Exanthematous reactions, fever, nausea, headache, fatigue, somnolence, vomiting, diarrhea, abdominal pain, and myalgia have been the most frequently reported symptoms related to nevirapine therapy. ${ }^{44}$ Regarding clinical laboratory data, the most frequently observed laboratory test abnormalities are elevations in liver-function test results, including alanine transaminase (ALT) aspartate transaminase (AST), gamma glutamyl transpeptidase, total bilirubin, and alkaline phosphatase. Cases of anemia and neutropenia may be associated with nevirapine therapy. The following adverse events that may be causally related to the administration of nevirapine IR have been reported and could be expected with the XR formulation (Table 4).

\section{Skin and subcutaneous tissues}

The most common clinical toxicity of nevirapine is an exanthematous reaction appearing in $17 \%$ of patients. ${ }^{45}$ It is usually maculopapular and erythematous, with or without pruritus, and is located in the trunk, face, and extremities. Some patients may require hospitalization, and $7 \%$ require discontinuation of the drug compared with $1.7 \%$ given efavirenz. The frequency of severe (grade 3-4) exanthematous reaction in the $2 \mathrm{NN}$ trial was $6 \%$ in patients with CD4 lymphocyte cell count of $200 / \mathrm{mm}^{3}$ or greater and $1 \%-2 \%$ in those with CD4 lymphocyte cell count less than $200 / \mathrm{mm}^{3}$.
Indications of discontinuation of nevirapine due to exanthematous reaction are the presence of fever, blisters, mucous membrane involvement, conjunctivitis, edema, arthralgias, or malaise. Patients with rash should be assessed for hepatotoxicity, as the two may occur together. The majority of severe exanthematous reactions occurred within the first 6 weeks of treatment.

Regarding safety data for nevirapine XR in antiretroviral treatment-naïve patients, the VERxVE trial showed that severe or life-threatening exanthematous reactions attributed to nevirapine occurred in $1.1 \%$ of patients during the leadin phase with nevirapine IR, and in $0.8 \%$ and $0.6 \%$ of the nevirapine IR and nevirapine XR groups, respectively, during the randomization phase. The trial reported five cases of Stevens-Johnson syndrome, all of which occurred within the first 30 days of nevirapine treatment. ${ }^{13}$ In the TRANxITION trial, in which patients on nevirapine IR were randomized to receive nevirapine XR or to continue with nevirapine IR, no grade 3 or 4 exanthematous reactions was observed in either group. ${ }^{38}$

\section{Hepatobiliary}

Early hepatotoxicity usually occurs in the first 6 weeks and appears to be a hypersensitivity reaction. ${ }^{45}$ It may be accompanied by drug rash, eosinophilia, and systemic symptoms (DRESS syndrome). This adverse reaction differs from

Table 4 Nevirapine XR safety (there are no new adverse drug reactions for nevirapine-XR that have not been previously identified for nevirapine-IR)

\begin{tabular}{|c|c|c|c|c|}
\hline Disorder & $\begin{array}{l}\text { Very common } \\
\text { (frequency }>10 \% \text { ) }\end{array}$ & $\begin{array}{l}\text { Common } \\
\text { (frequency 1\%-10\%) }\end{array}$ & $\begin{array}{l}\text { Uncommon } \\
\text { (frequency } 0.1 \%-1 \% \text { ) }\end{array}$ & $\begin{array}{l}\text { Rare } \\
\text { (frequency } 0.01 \%-0.1 \% \text { ) }\end{array}$ \\
\hline Gastrointestinal & & $\begin{array}{l}\text { Nausea, vomiting, } \\
\text { abdominal pain, diarrhea }\end{array}$ & & \\
\hline Hematologic & & Granulocytopenia & Anemia & \\
\hline Hepatobiliary & & $\begin{array}{l}\text { Hepatitis (I.2\%); liver } \\
\text { function tests abnormal }\end{array}$ & Jaundice & $\begin{array}{l}\text { Liver failure/fulminant } \\
\text { hepatitis (may be fatal) }\end{array}$ \\
\hline Immune system & & $\begin{array}{l}\text { Hypersensitivity (including } \\
\text { anaphylactic reaction, } \\
\text { angioedema, urticaria) }\end{array}$ & $\begin{array}{l}\text { Drug rash with eosinophilia } \\
\text { and systemic symptoms, } \\
\text { anaphylactic reaction }\end{array}$ & \\
\hline $\begin{array}{l}\text { Musculoskeletal, } \\
\text { connective tissue } \\
\text { and bone }\end{array}$ & & Myalgia & Arthralgia & \\
\hline Nervous system & & Headache & & \\
\hline $\begin{array}{l}\text { Skin and } \\
\text { subcutaneous tissue }\end{array}$ & $\begin{array}{l}\text { Exanthematous } \\
\text { reaction }\end{array}$ & & $\begin{array}{l}\text { Stevens-Johnson syndrome } \\
(0.3 \%) \text {, toxic epidermal } \\
\text { necrolysis (may be fatal), } \\
\text { urticaria, angioedema }\end{array}$ & \\
\hline General symptoms & & Fatigue, pyrexia & Fever & \\
\hline $\begin{array}{l}\text { Laboratory } \\
\text { investigations }\end{array}$ & & $\begin{array}{l}\text { Liver-function test abnormal } \\
\text { (ALT/AST increased; GGT } \\
\text { increased) }\end{array}$ & $\begin{array}{l}\text { Blood phosphorus decreased, } \\
\text { blood pressure increased }\end{array}$ & \\
\hline
\end{tabular}

Abbreviations: ALT, alanine transaminase; AST, aspartate transaminase; GGT, gamma glutamyl transpeptidase. 
elevation of transaminases noted with other antiretroviral drugs in that it (1) is symptomatic hepatitis, (2) may progress to liver necrosis and death even with early detection of drug discontinuation, (3) usually occurs in the first 16 weeks (more usually in the first 6 weeks), and (4) occurs primarily with high CD4 lymphocyte cell counts, especially in women. The mechanism of this reaction is unknown, but since it is related to high CD4 lymphocyte cell counts an immune substrate with an associated genetic predisposition is suggested. ${ }^{46}$ In November 2000, the US Food and Drug Administration issued a black-box warning drawing attention to nevirapine's potential to cause serious liver damage as well as life-threatening hepatic failure, particularly in HIV-infected women with CD4 lymphocyte cell counts greater than $250 / \mathrm{mm}^{3}$ and HIV-infected men with CD4 lymphocyte cell counts greater than $400 / \mathrm{mm}^{3}$. It has been shown that the rate of symptomatic hepatotoxicity was $11 \%$ in women with CD4 lymphocyte cell counts greater than $250 / \mathrm{mm}^{3}$ and only $0.9 \%$ in women with lower CD4 cells counts at baseline. ${ }^{47}$ For men, there was also an increase in hepatotoxicity severity for those with CD4 lymphocyte cell counts of $400 / \mathrm{mm}^{3}$ or greater, but the rates were much lower $-6.4 \%$ versus $2.3 \%{ }^{48}$ Additional risk factors for severe hepatotoxicity are coinfection by hepatitis $B$ virus, hepatitis $C$ virus, or baseline elevations of ALT/AST levels greater than 2.5 times the upper limit of normal. ${ }^{48}$ In September 2010, the European Medicines Agency approved a modification allowing the use of nevirapine regardless of CD4 lymphocyte count in patients who had an undetectable viral load (HIV-1 RNA concentration of fewer than 50 copies $/ \mathrm{mL}) .{ }^{49}$ This update was made after reviewing retrospective cohort studies (EUROSIDA Cohort) and other observational studies (ATHENA cohort and multi-ATHENA cohort) that proved the safety of nevirapine in more than 12,000 patients who had no detectable viral load. ${ }^{50-56}$ Nevertheless, the 14-day lead-in period with nevirapine IR $200 \mathrm{mg}$ daily dosing must be strictly followed, since it has been demonstrated to reduce the frequency of rash. If rash persists beyond the 14-day lead-in period with nevirapine IR, dosing with nevirapine XR should not be continued. Lead-in dosing with $200 \mathrm{mg}$ once-daily immediate-release nevirapine IR should not be continued beyond 28 days, at which point an alternative regimen should be sought.

The Centers for Disease Control and Prevention issued a warning against using nevirapine for post-exposure prophylaxis based on reports of two health-care workers suffering from fulminant hepatitis. ${ }^{57}$ Patients treated with nevirapine may also develop hepatotoxicity later in the course of therapy, more benign and similar to hepatitis caused by other antiretroviral drugs. This hepatitis is characterized by asymptomatic elevation of transaminases. The management guidelines for early liver injury include frequent monitoring of transaminases in the first 12-16 weeks and prompt discontinuation of nevirapine if the diagnosis is suspected. For later asymptomatic transaminitis, the approach is less clear, but many experts recommend discontinuation of nevirapine if ALT is greater than 5-10 times the upper limit of normality. ${ }^{58}$

The VERxVE trial prospectively collected data on potential symptoms of hepatic events in 1011 patients enrolled with lymphocyte CD4 counts of fewer than 250 cells $/ \mathrm{mm}^{3}$ for women and fewer than 400 cells $/ \mathrm{mm}^{3}$ for men. The incidence of symptomatic hepatotoxicity during the nevirapine IR lead-in phase was $0.5 \%$. After the lead-in period, the incidence of symptomatic hepatic events was $2.8 \%$ in the nevirapine IR group and $1.6 \%$ in the nevirapine XR group. Overall, there was a comparable incidence of symptomatic hepatic events among men and women. ${ }^{13}$

In the TRANxITION trial, no grade 3 or 4 clinical hepatic events were observed in either treatment group. ${ }^{38}$

\section{Conclusion}

In summary, nevirapine is a non-nucleoside reverse-transcriptase inhibitor with an extensive history in combination antiretroviral treatments. Nevirapine shortcomings are low genetic barrier, risk of severe skin and liver adverse reactions, and requiring twice-daily dosing. Recent data show that nevirapine used as single dose for the prevention of perinatal HIV-1 transmission is a risk factor for emergence of HIV-1-resistant mutations that reduce efficacy of nevirapinebased antiretroviral treatment regimens in both mothers and infants. On the other hand, nevirapine has been considered as a first-line drug in developing countries due to its high potency, no food effect, low pill burden, and low cost. Clinical trials published in the last 2 years showed that nevirapine was not inferior to ritonavir-boosted lopinavir or ritonavir-boosted atazanavir in adult antiretroviral treatment-naïve patients. An XR formulation of nevirapine that has been recently commercialized may offer improved treatment options for once-daily antiretroviral regimens, with greater convenience and patient adherence.

\section{Disclosure}

Javier Ena received honoraria from Bristol-Myers Squibb, Gilead, Abbott, and Boehringer Ingelheim as clinical advisor in 2011-2012. Concepción Amador received honoraria from Abbott, Boehringer Ingelheim, Bristol-Myers Squibb, Gilead, 
Janssen-Cilag, and MSD as clinical advisor in 2011-2012. Conxa Benito received honoraria from Bristol-Myers Squibb, Gilead, Janssen-Cilag, and Boehringer Ingelheim as clinical advisor in 2011-2012. Francisco Pasquau received honoraria from Abbott, Boehringer Ingelheim, Bristol-Myers Squibb, Gilead, Janssen-Cilag, and MSD as clinical advisor in 20112012. Boehringer-Ingelheim had no role in the preparation, review, or approval of the manuscript.

\section{References}

1. Renaud-Théry F, Avila-Figueroa C, Stover J, et al. Utilization patterns and projected demand of antiretroviral drugs in low- and middle-income countries. AIDS Res Treat. 2011;2011:749041.

2. Bendavid E, Grant P, Talbot A, Owens DK, Zolopa A. Cost-effectiveness of antiretroviral regimens in the World Health Organization's treatment guidelines: a South African analysis. AIDS. 2011;25(2): 211-220.

3. Phillips E, Gutiérrez S, Jahnke N, et al. Determinants of nevirapine hypersensitivity and its effect on the association between hepatitis $\mathrm{C}$ status and mortality in antiretroviral drug-naive HIV-positive patients. AIDS. 2007;21(12):1561-1568.

4. Ngo-Giang-Huong N, Jourdain G, Amzal B, et al. Resistance patterns selected by nevirapine vs efavirenz in HIV-infected patients failing first-line antiretroviral treatment: a bayesian analysis. PLoS One. 2011;6(11):e27427.

5. Boehringer Ingelheim Pharmaceuticals. Highlights of prescribing information. Available from: http://bidocs.boehringer-Ingelheim. com/BIWebAccess/ViewServlet.ser?docBase=renetnt\&folderPath=/ Prescribing+Information/PIs/Viramune/Viramune.pdf. Accessed July 15, 2012.

6. Patel SS, Benfield P. New drug profile: nevirapine. Clin Immunother. 1986;6(4):307-317.

7. Ren J, Bird LE, Chamberlain PP, Stewart-Jones GB, Stuart DI, Stammers DK. Structure of HIV-2 reverse transcriptase at 2.35-A resolution and mechanism of resistance to non-nucleoside inhibitors. Proc Natl Acad Sci U S A. 2002;99(22):14410-14415.

8. Conway B, Wainberg MA, Hall D. Development of drug resistance in patients receiving combinations of zidovudine, didanosine and nevirapine. AIDS. 2001;15(10):1269-1274.

9. Duong M, Buisson M, Peytavin G, et al. Low trough plasma concentrations of nevirapine associated with virologic rebounds in $\mathrm{HIV}$-infected patients who switched from protease inhibitors. Ann Pharmacother. 2005;39(4):603-609.

10. González de Requena D, Bonora S, et al. Nevirapine plasma exposure affects both durability of viral suppression and selection of nevirapine primary resistance mutations in a clinical setting. Antimicrob Agents Chemother. 2005;49(9):3966-3969.

11. Vidal C, Arnedo M, Garcia F. Genotypic and phenotypic resistance patterns in early-stage HIV-1-infected patients failing initial therapy with stavudine, didanosine and nevirapine. Antivir Ther. 2002;7(4):283-287.

12. Kiertiburanakul S, Wiboonchutikul S, Sukasem C, Chantratita W, Sungkanuparph S. Using of nevirapine is associated with intermediate and reduced response to etravirine among HIV-infected patients who experienced virologic failure in a resource-limited setting. J Clin Virol. 2010;47(4):330-334.

13. Gathe J, Andrade-Villanueva J, Santiago S, et al. Efficacy and safety of nevirapine extended-release once daily versus nevirapine immediaterelease twice daily in treatment-naive HIV-1-infected patients. Antivir Ther. 2011;16(5):759-769.

14. Food and Drug Administration. Approval of Viramune XR (nevirapine) $400 \mathrm{mg}$ extended release tablet. Available from: http:// www.fda.gov/ForConsumers/ByAudience/ForPatientAdvocates/ HIVandAIDSActivities/ucm248800.htm. Accessed June 15, 2012.
15. Macha S, Yong CL, Darrington T, et al. In vitro-in vivo correlation for nevirapine extended release tablets. Biopharm Drug Dispos. 2009;30(9):542-550.

16. Battegay M, Arasteh K, Plettenberg A, et al. Bioavailability of extendedrelease nevirapine 400 and $300 \mathrm{mg}$ in HIV-1: a multicenter, open label study. Clin Ther. 2011;33(9):1308-1320.

17. Riska P, Lamson M, MacGregor T, et al. Disposition and biotransformation of the antiretroviral drug nevirapine in humans. Drug Metab Dispos. 1999;27(8):895-901.

18. Giaquinto C, Anabwani G, Feiterna-Sperling G, et al. Steady-state pharmacokinetic parameters of nevirapine extended release formulation tablets in children with HIV-1 infection: an open-label, multiple-dose, cross-over study. 18th CROI Conference on Retroviruses and Opportunistic Infections; February 27-March 2, 2011; Boston, MA; Abstract 716.

19. Violari A, Lindsey JC, Hughes MD, et al. Nevirapine versus ritonavir-boosted lopinavir for HIV-infected children. $N$ Engl J Med. 2012;366(25):2380-2389.

20. McIntyre JA, Hopley M, Moodley D, et al. Efficacy of short-course AZT plus 3TC to reduce nevirapine resistance in the prevention of mother-to-child HIV transmission: a randomized clinical trial. PLoS Med. 2009;6(10):e1000172.

21. van Leth F, Phanuphak P, Ruxrungtham K, et al. Comparison of first-line antiretroviral therapy with regimens including nevirapine, efavirenz, or both drugs, plus stavudine and lamivudine: a randomised open-label trial, the 2NN Study. Lancet. 2004;363(9417):1253-1263.

22. Lockman S, Hughes MD, McIntyre J, et al. Antiretroviral therapies in women after single-dose nevirapine exposure. $N$ Engl J Med. 2010;363(16):1499-1509.

23. de Maat MM, Nellen JF, Huitema AD, et al. Race is not associated with nevirapine pharmacokinetics. Ther Drug Monit. 2004;26(4): 456-458.

24. Izzedine H, Launay-Vacher V, Aymard G, Legrand M, Deray G. Pharmacokinetic of nevirapine in haemodialysis. Nephrol Dial Transplant. 2001;16(1):192-193.

25. Dominguez $\mathrm{S}$, Ghosn J, Peytavin G, et al. Impact of hepatitis $\mathrm{C}$ and liver fibrosis on antiretroviral plasma drug concentrations in HIV-HCV co-infected patients: the HEPADOSE study. J Antimicrob Chemother. 2010;65(11):2445-2449.

26. Lamorde M, Byakika-Kibwika P, Okaba-Kayom V, et al. Nevirapine pharmacokinetics when initiated at $200 \mathrm{mg}$ or $400 \mathrm{mg}$ daily in HIV-1 and tuberculosis co-infected Ugandan adults on rifampicin. JAntimicrob Chemother. 2011;66(1):180-183.

27. Manosuthi W, Sungkanuparph S, Tantanathip P, et al. A randomized trial comparing plasma drug concentrations and efficacies between 2 non-nucleoside reverse-transcriptase inhibitor-based regimens in HIVinfected patients receiving rifampicin: the N2R Study. Clin Infect Dis. 2009;48(12):1752-1759.

28. Swaminathan S, Padmapriyadarsini C, Venkatesan P, et al. Efficacy and safety of once-daily nevirapine- or efavirenz-based antiretroviral therapy in HIV-associated tuberculosis: a randomized clinical trial. Clin Infect Dis. 2011;53(7):716-724.

29. Mankhatitham W, Lueangniyomkul A, Manosuthi W. Hepatotoxicity in patients co-infected with tuberculosis and HIV-1 while receiving nonnucleoside reverse transcriptase inhibitor-based antiretroviral therapy and rifampicin-containing anti-tuberculosis regimen. Southeast Asian J Trop Med Public Health. 2011;42(3):651-658.

30. Podzamczer D, Andrade-Villanueva J, Clotet B, et al. Lipid profiles for nevirapine vs atazanavir/ritonavir, both combined with tenofovir disoproxil fumarate and emtricitabine over 48 weeks, in treatment-naïve HIV-1infected patients (the ARTEN study). HIV Med. 2011;12(6):374-382.

31. Aslangul E, Assoumou L, Bittar R, et al. Rosuvastatin versus pravastatin in dyslipidemic HIV-1-infected patients receiving protease inhibitors: a randomized trial. AIDS. 2010;24(1):77-83.

32. Pelet A, Favrat B, Cavassini M, Eap CB, Besson J, Monnat M. Usefulness of methadone plasma concentration measurement in patients receiving nevirapine or efavirenz. Am J Drug Alcohol Abuse. 2011;37(4):264-268. 
33. Clarke SM, Mulcahy FM, Tjia J, et al. Pharmacokinetic interactions of nevirapine and methadone and guidelines for use of nevirapine to treat injection drug users. Clin Infect Dis. 2001;33(9):1595-1597.

34. Negredo E, Moltó J, Burger D, et al. Lopinavir/ritonavir plus nevirapine as a nucleoside-sparing approach in antiretroviral-experienced patients (NEKA study). J Acquir Immune Defic Syndr. 2005;38(1):47-52.

35. Negredo E, Miró O, Rodríguez-Santiago B, et al. Improvement of mitochondrial toxicity in patients receiving a nucleoside reversetranscriptase inhibitor-sparing strategy: results from the Multicenter Study with Nevirapine and Kaletra (MULTINEKA). Clin Infect Dis. 2009;49(6):892-900.

36. Soriano V, Arasteh K, Migrone H, et al. Nevirapine versus atazanavir/ ritonavir, each combined with tenofovir disoproxil fumarate/ emtricitabine, in antiretroviral-naive HIV-1 patients: the ARTEN trial Antivir Ther. 2011;16(3):339-348.

37. DeJesús E, Mills A, Bhatti L, et al. A randomised comparison of safety and efficacy of nevirpine vs atazanavir/ritonavir combined with tenofovir/emtricitabine in treatment-naïve patients. Int J Clin Pract. 2011;65(12):1240-1249.

38. Arasteh K, Ward D, Plettenberg A, et al. 24 Wk efficacy and safety of transitioning virologically stable HIV-1 patients from IR nevirapine $200 \mathrm{mg}$ BID to nevirapine XR $400 \mathrm{mg}$ QD (TRANxITION). 50th Interscience Conference on Antimicrobial Agents and Chemotherapy (ICAAC); September 12-15, 2010; Boston, MA; Abstract H-207.

39. Guay LA, Musoke P, Fleming T, et al. Intrapartum and neonatal single-dose nevirapine compared with zidovudine for prevention of mother-to-child transmission of HIV-1 in Kampala, Uganda: HIVNET 012 randomised trial. Lancet. 1999;354(9181):795-802.

40. Eshleman SH, Mracna M, Guay LA, et al. Selection and fading of resistance mutations in women and infants receiving nevirapine to prevent HIV-1 vertical transmission (HIVNET 012). AIDS. 2001;15(15): 1951-1957.

41. Kesho Bora Study Group, de Vincenzi I. Triple antiretroviral compared with zidovudine and single-dose nevirapine prophylaxis during pregnancy and breastfeeding for prevention of mother-to-child transmission of HIV-1 (Kesho Bora study): a randomised controlled trial. Lancet Infect Dis. 2011;11(3):171-180.

42. Coovadia HM, Brown ER, Fowler MG, et al. Efficacy and safety of an extended nevirapine regimen in infant children of breastfeeding mothers with HIV-1 infection for prevention of postnatal HIV-1 transmission (HPTN 046): a randomised, double-blind, placebo-controlled trial. Lancet. 2012;379(9812):221-228.

43. Omer SB, Six Week Extended Dose Nevirapine (SWEN) Study Team. Twelve-month follow-up of Six Week Extended Dose Nevirapine randomized controlled trials: differential impact of extended-dose nevirapine on mother-to-child transmission and infant death by maternal CD4 cell count. AIDS. 2011;25(6):767-776.

44. Pollard RB, Robinson P, Dransfield K. Safety profile of nevirapine, a non-nucleoside reverse transcriptase inhibitor for the treatment of human immunodeficiency virus infection. Clin Ther. 1998;20(6):1071-1092.
45. Dieterich DT, Robinson PA, Love J, Stern JO. Drug-induced liver injury associated with the use of non-nucleoside reverse-transcriptase inhibitors. Clin Infect Dis. 2004;38 Suppl 2:S80-S89.

46. Haas DW, Bartlett JA, Andersen JW, et al. Pharmacogenetics of nevirapine-associated hepatotoxicity: an Adult AIDS Clinical Trials Group collaboration. Clin Infect Dis. 2006;43(6):783-786.

47. Sanne I, Mommeja-Marin H, Hinkle J, et al. Severe hepatotoxicity associated with nevirapine use in HIV-infected subjects. $J$ Infect Dis. 2005;191(6):825-829.

48. Stern JO, Robinson PA, Love J, Lanes S, Imperiale MS, Mayers DL. A comprehensive hepatic safety analysis of nevirapine in different populations of HIV infected patients. J Acquir Immune Defic Syndr. 2003;34 Suppl 1:S21-S33.

49. European Medicines Agency. Nevirapine - summary of product characteristics. Available at: http://www.ema.europa.eu/docs/en_GB/ document_library/EPAR_-_Product_Information/human/000183/ WC500051481.pdf. Accessed June 14, 2012.

50. Kesselring AM, Wit FW, Sabin CA, et al. Risk factors for treatmentlimiting toxicities in patients starting nevirapine-containing antiretroviral therapy. AIDS. 2009;23(13):1689-1699.

51. Mocroft A, Staszewski S, Weber R, et al. Risk of discontinuation of nevirapine due to toxicities in antiretroviral-naive and -experienced HIV-infected patients with high and low CD4+ T-cell counts. Antivir Ther. 2007;12(3):325-333.

52. Wit FW, Kesselring AM, Gras L, et al. Discontinuation of nevirapine because of hypersensitivity reactions in patients with prior treatment experience, compared with treatment-naive patients: the ATHENA cohort study. Clin Infect Dis. 2008;46(6):933-940.

53. Calmy A, Vallier N, Nguyen A, et al. Safety and efficacy of once-daily nevirapine dosing: a multicohort study. Antivir Ther. 2009;14(7): 931-938.

54. Manfredi R, Calza L. Nevirapine versus efavirenz in 742 patients: no link of liver toxicity with female sex, and a baseline CD4 cell count greater than 250 cells/microl. AIDS. 2006;20(17):2233-2236.

55. Antela A, Ocampo A, Gómez R, et al. Liver toxicity after switching or simplifying to nevirapine-based therapy is not related to CD4 cell counts: results of the TOSCANA study. HIV Clin Trials. 2010;11(1):11-17.

56. De Lazzari E, León A, Arnaiz JA, et al. Hepatotoxicity of nevirapine in virologically suppressed patients according to gender and CD4 cell counts. HIV Med. 2008;9(4):221-226.

57. Centers for Disease Control and Prevention (CDC). Serious adverse events attributed to nevirapine regimens for postexposure prophylaxis after HIV exposures - worldwide, 1997-2000. MMWR Morb Mortal Wkly Rep. 2001;49(51-52):1153-1156.

58. Ena J, Amador C, Benito C, Fenoll V, Pasquau F. Risk and determinants of developing severe liver toxicity during therapy with nevirapine- and efavirenz-containing regimens in $\mathrm{HIV}$-infected patients. Int JSTD AIDS. 2003;14(11):776-781
HIV/AIDS - Research and Palliative Care

\section{Publish your work in this journal}

HIV/AIDS - Research and Palliative Care is an international, peerreviewed open-access journal focusing on advances in research in HIV, its clinical progression and management options including antiviral treatment, palliative care and public healthcare policies to control viral spread. The journal welcomes original research, basic science,

\section{Dovepress}

clinical \& epidemiological studies, reviews \& evaluations, expert opinion \& commentary, case reports \& extended reports. The manuscript management system is completely online and includes a very quick and fair peer-review system. Visit http://www.dovepress.com/ testimonials.php to read real quotes from published authors. 